


\title{
o1. Yabancılara özel amaçlı Türkçe öğretimi bağlamında iş Türkçesi: tanımlar ve sinirliklar
}

Volkan KURT1

APA: Kurt, V. (2021). Yabancılara özel amaçlı Türkçe öğretimi bağlamında iş Türkçesi: tanımlar ve sinırlıklar. RumeliDE Dil ve Edebiyat Araştırmalar Dergisi, (24), 1-9. DOI: 10.29000/rumelide.990048.

\section{$\ddot{O} \mathbf{z}$}

Yabancı dil olarak Türkçenin iş dili bağlamında öğretimine giderek artan bir talep vardır. Başta ticari saha olmak üzere çeşitli iş kollarında Türkçeyi öğrenmek isteyen profesyonellerin sayısı gün geçtikçe artmaktadır. İş dili, ticaret yaşamında önemli bir işleve sahiptir. İş dünyasında kurumların şirket içi iletişimleri, müşteriye bir ürün, mal ya da hizmeti pazarlamaları iş dili üzerinden gerçekleşmektedir. İş dünyasında iş dilinin doğru ve etkili kullanımı verimliliği arttırması açısından önemlidir ve temel bir ihtiyaçtır. Bu çalışmada giderek artan iş Türkçesi ihtiyacını karşılamak için oluşturulacak materyallerde ve açılacak kurslara kuramsal alt yapı desteği sağlamak amaçlanmaktadır. Bu bağlamda özel amaçlı dil öğretiminin tanımı, sınırları ve sınıflandırılması üzerinde durulduktan sonra iş Türkçesi öğretiminin tanımı ve sınıflandırılması yapılmıştır. Yabanıı dil olarak iş Türkçesi öğretiminde öğreticilere ve materyal tasarımcılarına yol gösterici olması için iş Türkçesi öğretiminin özellikleri ortaya konmuştur. Araştırmada nitel araştırma yöntemlerine dayalı literatür taraması temelli derleme çalışması yapılmıştır.

Anahtar kelimeler: Yabancı dil olarak özel amaçlı Türkçe öğretimi, iş Türkçesi, akademik Türkçe, mesleki Türkçe, iş dili

\section{Business Turkish in the context of teaching Turkish for specific purposes to foreigners: definitions and limitations}

\begin{abstract}
There is an increasing demand for teaching Turkish as a foreign language in the context of a business language. The number of professionals who want to learn Turkish in various business fileds, especially in the commercial field, is increasing day by day. Business language has an important function in business life. In the business world, the internal communications of the institutions and the marketing of a product, product or service to the customer are carried out through the business language. The correct and effective use of business language in the business world is important in terms of increasing productivity and is a basic need. In this study, it is aimed to provide theoretical infrastructure support for the materials to be created and the courses to be opened to meet the increasing need for business Turkish. In this context, after focusing on the definition, limits and classification of special purpose language teaching, the definition and classification of business Turkish teaching has been made. In order to guide the instructors and material designers in the teaching of business Turkish as a foreign language, the characteristics of business Turkish teaching
\end{abstract}

Dr. Öğr. Gör., Adana Alparslan Türkeş Bilim ve Teknoloji Üniversitesi, Türkçe Öğretimi Uygulama ve Araştırma Merkezi, (Adana, Türkiye) kurtvolkan@ hotmail.com, ORCID ID: 00oo-0001-6265-6548 [Araştırma makalesi, Makale kayıt tarihi: 10.05.2021-kabul tarihi: 20.09.2021; DOI: 10.29000/rumelide.990048]

Adres $\mid$ Address

RumeliDE Dil ve Edebiyat Araşturmaları Dergisi $\quad$ RumeliDE Journal of Language and Literature Studies Osmanağa Mahallesi, Mürver Çiçeği Sokak, No:14/8 $\quad$ Osmanağa Mahallesi, Mürver Çiçeği Sokak, No:14/8 Kadıköy - ISTANBUL / TÜRKIYE 34714 Kadıköy - ISTANBUL / TURKEY 34714 e-posta: editor@rumelide.com e-mail: editor@rumelide.com, tel: +90 505 7958124, +90 2167730616 phone: +90 505 7958124, +90 2167730616 
Business Turkish in the context of teaching Turkish for specific purposes to foreigners: definitions and limitations / V. Kurt (pp. 1-9)

have been revealed. In the research, a review study based on literature review based on qualitative research methods was conducted.

Keywords: Teaching Turkish as a foreign language for specicif purposes, business Turkish, academic Turkish, occupational Turkish, business language

\section{Giriş}

II. Dünya Savaşı’ndan sonra dünyada ortaya çıkan ancak asıl büyük gelişimini 196o’lardaki petrol krizi ile İngilizcenin özel amaçlar öğretimi ile gösteren özel amaçlı dil öğretimi yabancı dil öğretiminin bir parçasıdır. Özel amaçlı dil öğretiminde ilk sorulacak soru öğrenicinin dili neden öğrenmek istediğidir. Bu soruya verilen cevaplar farklı öğrenici gruplarının farklı iletişimsel ihtiyaçları olduğunu ortaya koyar. $\mathrm{Bu}$ bağlamda özel amaçlı bir dil kursu tasarlanırken öğrenicinin dil ihtiyaçlarının yanı sıra beceri ihtiyaçları ve ilgi alanları göz önünde bulundurulur. Bu hâliyle özel amaçlı dil kursları müfredat, materyal tasarımı ve ölçme değerlendirme bakımından genel dil kurslarından ayrılır.

Çalışmamıza konu ettiğimiz iş Türkçesi öğretimi, özel amaçlı Türkçe öğretiminin bir alt koludur. Türkiye Odalar ve Borsalar Birliği (TOBB, 2021) raporlarına göre ülkemizde kurulan yabancı ortaklı şirket sayısı 2017'de 6.731, 2018'de 13.405, 2019'da 12.634, 2020'de 9.490, 2021 Ocak ve Şubat aylarında toplam 2.016'dır. T.C. Aile, Çalışma ve Sosyal Hizmetler Bakanlığının son olarak yayımlanan Çalışma Hayatı İstatistikleri (2019) raporuna göre ekonomik faaliyetlere göre yabancılara verilen çalışma izni sayısı 145.232'dir. İzinlerin verildiği ilgili çalışma alanları ise ağırlıklı olarak konaklama, inşaat, ticaret, büro faaliyetleri, eğitim, sağlık hizmetleri, yiyecek içecek hizmetleri gibidir. Bu şirketlerin sermayesini ağırlıklı olarak İran, Ürdün, Suriye, Irak, Lübnan, Mısır, Almanya, ABD, Azerbaycan, İtalya, İngiltere, Afganistan, Suudi Arabistan, Özbekistan, BAE, İsviçre, Romanya, Yunanistan, Rusya Federasyonu, Filistin, Yemen vd. ülkeler oluşturmaktadır. Veriler mesleki amaçlarla Türkçe öğrenmek isteyecek öğrenici varlığını göstermektedir. Bunun yanı sıra Türk şirketlerinin Türkiye dışındaki çalışma sahaları genişledikçe yurt dışında da iş Türkçesi öğrenme talepleri oluşmaktadır.

Gittikçe hız kazanan yabancı dil olarak Türkçe öğretiminde hem kuramsal hem de uygulamalı çalışmalar artmaktadır. Ancak bu alanın bir alt kolu olan özel amaçlı Türkçe öğretimi hem kuram hem de uygulama olarak istenen noktada değildir. Özel amaçlı Türkçe öğretiminin tanımı ve sınırları konusunda yeterli kuramsal veriden yoksun olan sahada uygulama çalışmalarında da zorluklar yaşanmaktadır. İş Türkçesi de özel amaçlı Türkçenin talep gören bir alt kolu olarak yeterince incelenmemiştir. İş Türkçesinin tanımı ve sınırları da alanyazında yeterince anlaşılamamıştır. Barın ve Temizyürek (2018) özel amaçlı Türkçe öğretiminde müfredat, ders planı ve materyal çalışmalarının eksikliğine dikkat çekerek mesleki ve akademik Türkçe arasındaki ayrımın kesinleştirilmesini; bunlara uygun materyallerin kullanılmasını vurgularlar.

$\mathrm{Bu}$ çalışmada özel amaçlı Türkçe öğretimi bağlamında iş Türkçesinin tanımı ve sınırlarını belirginleştirmek ve bu sayede sahada hem kuramsal çalışmalar yapan araştırmacılara hem de kurs ve materyal üreticilerine destek sunmak amaçlanmaktadır. Bu amaçla alanyazın taramasından yola çıkılarak aşağıdaki soruların cevapları aranmıştır:

1. Yabancı dil olarak özel amaçlı Türkçe öğretiminin tanımı, sınırları ve türleri nelerdir?

2. Yabancı dil olarak iş Türkçesi öğretiminin tanımı, türleri ve belirleyici özellikleri nelerdir?

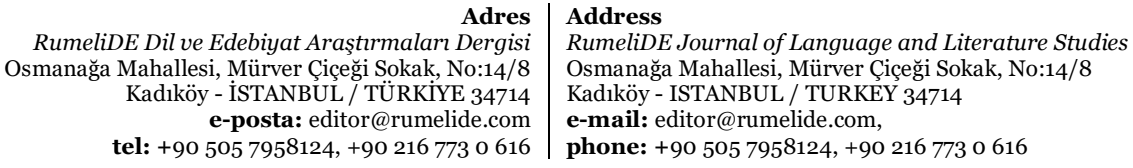


Çalışmada nitel araştırma yöntemine dayalı alanyazın taraması temelli derleme çalışması yöntemine başvurulmuştur.

\section{Özel amaçlı dil öğretimi}

Alanyazında özel amaçlı dil öğretiminin tanımlarına bakıldığında araştırmacıların fikir birliğine vardığını söylemek mümkün değildir. Hutchinson ve Waters (1991) özel amaçlı dil öğretiminin "bir ürün değil, yaklaşım olarak görülmesi” gerektiğini belirtirken Mackay ve Mountford (1978), dilin "fayda sağlayan pratik” yönüne vurgu yapar. Baştürkmen (2006) ise özel amaçlı dili “öğrenenleri hedefe doğru hızlandıran pratik bir çaba” olarak tanımlar.

Özel amaçlı dil öğretimi, genel dil öğretiminin en köklü öğretim yaklaşımlarından biridir. Özel amaçlı dil öğretimi eklektik bir yaklaşıma dayalı olup iletişimsel dil öğretimi, görev tabanlı öğretim, proje tabanlı öğrenme gibi teori ve uygulamalardan en yararlı ve etkili olanları ihtiyaçlar doğrultusunda birleştirir.

Özel amaçlı dil öğretimini “problem çözen” ve “amaca yönelik” bir yaklaşım olarak gören Belcher (2006) öğretmenin sezgisinin ve dil yapıları bilgisinin dil öğretiminde yetersiz kaldığının fark edilip dili belirli bağlamlarda kullanmanın öneminin anlaşılmasını bu alanın gelişiminde dönüm noktalarından biri olarak vurgular.

Sıklık çalışmalarını, sözlük bilimsel ve metne bütüncül yaklaşan çalışmaları takip eden ihtiyaç analizlerinin ortaya çlkmasıyla hedef dilin hangi yönleriyle öğretileceğine önceden karar vermek yerine öğrenici ihtiyaçlarına öncelik verildi. Bu noktada "genel dil öğrenicisinden" bahsetmek yerine "belirli dil öğrenicisinden” bahsedilmeye başlandı. Devamında öğrenicilerin yaşam ve öğrenim hedefleri, önceki dil bilgileri, hedef durumlara dair farkındalıkları gibi "özel ihtiyaçlarının” bilinmesinin faydası ortaya çlkmıştır. Bu aşamada özel amaçlı dil öğretimi öğrenici merkezli bir hâle gelmiştir. Böylelikle öğrenicilerin sadece dille ne yaptıklarına değil onu nasıl öğrendiklerine odaklanılmış ve öğrenicilerin katılımı teşvik edilmiştir. Bazı araştırmacılar (Douglas, 2000; Robinson, 1991) yukarıdaki gelişmelere ek olarak daha sosyal bir bakış açısıyla "dinamik, sürekli değişen ... iletişim durumundaki katılımcılar tarafından inşa edilen” söylem alanı görüşünü ortaya koymuşlardır. Anketler, röportajlar ve metin analizinin yanı sıra vaka çalışmaları ve topluluk etnografyaları özel amaçlı dil öğretimine veri sağlamıştır. Ancak söylem topluluklarının daha büyük sosyo-politik ve politik sistemlere dâhil olduğu ve dillerinin de genel dilin bir parçası olduğu fark edilmiştir (aktaran Belcher, 2006, s. 136). Bu bilgiler ışı̆̆ında özel amaçlı dil öğretimi ile genel amaçlı dil öğretiminin özelliklerinin tanımlanması ve değerlendirilmesi yerinde olacaktır:

\begin{tabular}{|c|c|}
\hline Özel Amaçlı Dil Öğretimi & Genel Amaçlı Dil Öğretimi \\
\hline Genellikle yetişkinler öğreniciler. & Her yaş grubundan öğreniciler. \\
\hline Ortak hedefli öğreniciler. & Farklı hedefli öğreniciler. \\
\hline Yüksek motivasyonlu öğreniciler. & Motivasyon düzeyleri farklı öğreniciler. \\
\hline Kısa dönemli kurslar. & Uzun dönemli kurslar. \\
\hline İhtiyaç analizi temelli. & Öğrenici ihtiyaçları göz önünde bulundurulmayabilir. \\
\hline Akademik, mesleki veya işyeri odaklı olmak. & Belirli bir odağı yoktur. \\
\hline Özel bir içeriği vardır. & Genel bir içeriği vardır. \\
\hline Öğreniciler genellikle temel bir dil bilgisine sahiptir. & Öğreniciler, her seviyeden olabilir. \\
\hline $\begin{array}{r}\text { Adres } \\
\text { RumeliDE Dil ve Edebiyat Araştrmaları Dergisi } \\
\text { Osmanağa Mahallesi, Mürver Ciçeği Sokak, No:14/8 } \\
\text { Kadıköy - İTANBUL / TÜRKIYY } 34714 \\
\text { e-posta: editor@rumelide.com } \\
\text { tel: +90 505 7958124, +90 216 } 7730616\end{array}$ & $\begin{array}{l}\text { Address } \\
\text { RumeliDE Journal of Language and Literature Studies } \\
\text { Osmanağa Mahallesi, Mürver Ciçeği Sokak, No:14/8 } \\
\text { Kadıköy - ISTANBUL / TURKEY } 34714 \\
\text { e-mail: editor@rumelide.com, } \\
\text { phone: +90 505 7958124, +90 } 216773 \text { o } 616\end{array}$ \\
\hline
\end{tabular}


Business Turkish in the context of teaching Turkish for specific purposes to foreigners: definitions and limitations / V. Kurt (pp. 1-9)

Belirli bir söz varlığına odaklanır.

Dil bilgisine sınırlı olarak odaklanabilir.

Belirli dil becerilerine odaklanabilir. -okuma, yazma vd.-

Bu kurslar konu edindiği alanın metodolojilerinden yararlanabilir.
Bütün bir söz varlığına odaklanır.

Bütün bir dil bilgisi sistemine odaklanır.

Dil becerilerine eşit derecede odaklanmaya çalışır.

Ülke/bölge bazlı genel metodolojiyi kullanma eğilimindedir.

Tablo 1. Özel amaçlı dil öğretimi ve genel amaçlı dil öğretimi kurslarının belirgin özellikleri (Woodrow, 2018, s. 23-24'ten uyarlanmıştır).

Araştırmacıların özel amaçlı dil öğretimiyle ilgili farklı tanım ve sınıflandırmaları olmakla birlikte bu öğretim yaklaşımı, "akademik ve mesleki dil öğretimi” olarak iki ana kola ayrılmıştır: Akademik dil öğretiminin genel akademik ve özel akademik dil öğretimi şeklinde iki alt başlıkla değerlendirildiğini; mesleki ya da akademik dil öğretiminin ilgili özel alanlara göre derinleştirildiğini ve alt başlıklarla tanımlandığını söylemek mümkündür. Sinıflandırma sistemlerinde önem arz eden bir diğer konu da öğrenicinin dil öğretimine katılma dönemidir. Öğrenicilerin mesleki/akademik deneyimleri öncesinde, esnasında ya da sonrasında özel amaçlı dil kurslarına katılması bütün bir öğretiminin niteliğini değiştirebilir. Nitekim öğrenicilerin dil öğretim kurslarına mesleki ya da akademik deneyimle, bilgiyle ve sahanın söz varlığına aşina olarak gelmesi kursların yapısını etkileyecektir. Deneyimli öğrenicilerin “öğretici dile”, deneyimsiz öğrenicilerin “uygulamalı dile” gereksinimleri vardır (Kurt, 2020, s. 145-146).

Akademik amaçlı dil öğretimi, öğrenicilere hedef dilde öğrenim becerilerini kazandırmayı amaçlayan bir özel amaçlı dil öğretim koludur. Bu saha; ön lisans, lisans ve lisansüstü akademik ortamları; sınıf ortamını, araştırma türlerini, öğrenci metinlerini, akademik iş ve işlemleri kapsar. Akademik dil; ders kitaplarından seminerlere, akademik makalelerden komite raporlarına, tez savunmalarına ve öğrenci belgelerine kadar çeşitlilik arz eden iletişim unsurlarını içerir (Hyland, 2006, s. 1). Akademik amaçlı dil öğretimi genel akademik ve özel akademik amaçlı olmak üzere iki alt başlıkla özelleştirilmiştir. Bu alt başlıklar; akademik dil, beceri ve üslup özelliklerinin öğretiminde ortak bir paydada buluşurken özel akademik amaçlı dil öğretimi doğrudan öğrenicinin ilgili disiplinel alanına (kimya, mühendislik, hukuk, ilahiyat, hemşirelik vd.) yönelik olması bakımından genel akademik amaçlı dil öğretiminden ayrılır.

Mesleki amaçlı dil öğretimi "akademik olmayan" amaçları içeren; belirli bir meslekle ilgili iş becerilerini ve dilsel yapıları öğretmeyi amaçlayan bir özel amaçlı dil öğretimi koludur. Mesleki dil öğretimi, iş hayatının profesyonellerine yönelik olabileceği gibi mesleki bir alanda öğrenim gören öğrencilere ya da bu alanın mezun, deneyimsiz işe başlamak isteyen bireylerine yönelik olabilir. Bu bakımdan mesleki dil öğretimi iki alt kola ayrılabilir: Mesleki amaçlı dil öğretimi, profesyonel meslek sahiplerine yönelik olduğunda yönetim, tıp, hukuk, askerlik ve ticaret gibi alanlara hizmet eden profesyonel amaçlar taşır. Meslek öğrencilerine yönelik mesleki dil öğretimi ise belirli bir mesleğin diline odaklanır. Mesleki dil öğretimi, mezun ve deneyimsiz meslek öğrencilerine de yönelik olabilir; bu durumda iş bulma, iş görüşmesi gibi becerilere ve öğrencileri kariyerlerinde başarıya ulaştırma gibi amaçlara odaklanır. Meslek öğrencileri, mesleki dil dersleriyle ileride mesleklerini yürütürken ihtiyaç duyacakları muhtemel dili ve becerileri öğrenirler.

Profesyonel mesleki amaçlı dil öğretiminin iki alt kolu vardır: Tıp, hukuk, askerlik gibi mesleklere yönelik dil öğretimi bir alt kolu oluştururken iş adamlarına yönelik iş dili öğretimi diğer bir alt kolu oluşturur. İş adamlarına yönelik iş dili öğretiminin diğer profesyonel alanlardan ayrı tutulmasının sebebi, iş dili öğretiminin iş becerilerini ve iş dilini içermesinin yanı sıra genel iletişim dilini de kapsayan

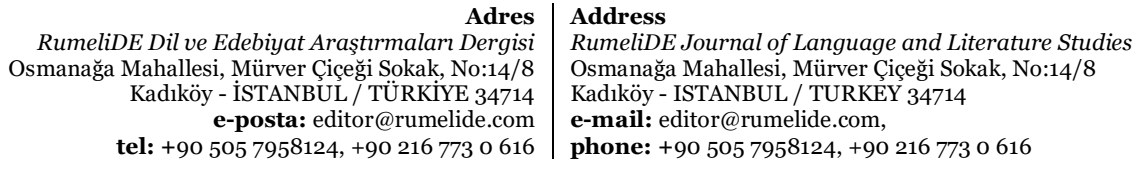


bir yönünün olmasıdır. İş dili öğretimini içerik ve kapsamına göre genel iş amaçlı dil öğretimi ve özel iş amaçlı dil öğretimi olarak iki alt kola ayırmak mümkündür.

Gerek akademik amaçlı gerekse mesleki amaçlı dil öğretimi öğrenici ihtiyaçlarına göre şekillenir. Ancak özel amaçlı dil öğretiminde açlklığa kavuşturulması gereken önemli bir nokta vardır: Bu yaklaşım tanımlanırken "öğrenici ihtiyaçlarının" gözetilmesi gerektiği vurgulanmakla birlikte bu ihtiyaçların akademik ya da mesleki olup olmadığının doğru sorgulanması gerekir. Bazı öğrenici ihtiyaçlarının özel amaçlı dilin değil genel amaçlı dilin kapsamında değerlendirilmesi gereklidir. Örnek olarak iş adamlarına açılan ve eksik oldukları dil bilgisi konularından oluşan destekleyici bir kurs -kursun amaçlarının belirli olmasına rağmen- özel amaçlı dil öğretimi kapsamında değerlendirilemez. Çünkü kursun odağı mesleki ya da akademik bir ihtiyaçla ilgili değil öğrenicilerin eksik oldukları dil bilgisi konularıdır.

Aşağıdaki tabloda görüleceği üzere dil öğretimi akışkan bir süreçtir. Tanımlayıcı bazı özelliklerden bahsedilmekle birlikte bazı sınırlar görünmez olabilir. Özel amaçlı dil öğretimini tanımlayıp sınıflandırırken bu noktayı göz önünde bulundurmak gereklidir.

Konumı

Tablo 2. Genelden özele giden yabancı dil öğretim süreçleri (Dudley-Evans ve St. Johns, 1998, s. 9'dan uyarlanmıştır).

Yukarıdaki bilgiler ışı̆ıında özel amaçlı Türkçe öğretimin belirli bir akademik ya da mesleki bağlam dâhilinde, öğrenicilerin özel iletişimsel ihtiyaçlarını temel alarak ilgili sahaya yönelik gerekli dil yapılarını, söz varlığını ve becerileri, çoğunlukla orta ve ileri düzey öğrenicilere öğretme amacı güden yabancı dil olarak Türkçe öğretimi yaklaşımı olduğu söylenebilir. Bu yaklaşım yalnızca Türkçenin yabancı dil olarak öğretiminde değil ana dili olarak öğretiminde de göz önünde bulundurulabilir. Özel amaçlı Türkçe öğretimi, akademik amaçlı ve mesleki amaçlı olmak üzere iki temel kola ayrılır.

İş Türkçesi öğretimi, mesleki amaçlı Türkçe öğretiminin bir alt koludur. Halihazırda iş ortamında çalışan veya çalışmaya hazırlananlara yönelik olup özel bir söz varlığına ve belirli iletişim türlerine odaklanır. İş Türkçesi öğretiminde amaç; belirli bir iş ortamında pazarlık yapmak, telefon etmek, sosyalleşmek, analiz etmek, ilan etmek gibi belirli amaçlarla kullanılan dili, sadece söz varlı̆̆ üzerinden değil iş becerileri üzerinden öğretmektir. İş Türkçesi “işi” odağına alır.

İş, kaynakların ve yeterliklerin alınıp verilmesi yani satma ve satın alınma kavramları üzerine kuruludur. Buna bağlı olarak iş dili; ticaret, ekonomi, bankacılık, finans, endüstri gibi sektörlerde ve ofis bağlamlarında mal ya da hizmet alım satımına yönelik olarak iş insanları tarafından kullanılan mesleki dildir. Bir başka deyişle iş dili "iş yaparken" kullanılan dildir (Kurt, 2020, s. 91-92). Bankacıllı dili, sigortacılık dili, turizm dili gibi örneklendirilebilir.

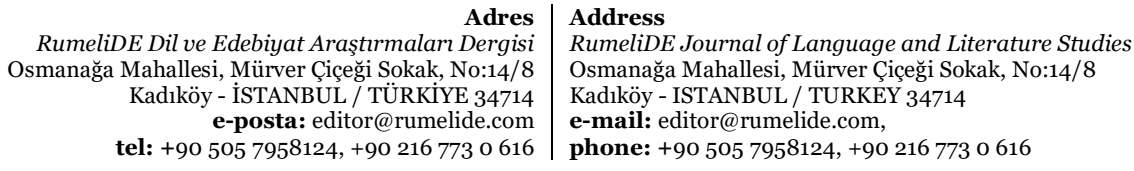


Business Turkish in the context of teaching Turkish for specific purposes to foreigners: definitions and limitations / V. Kurt (pp. 1-9)

İş Türkçesi öğretimini genel iş Türkçesi öğretimi ve özel iş Türkçesi öğretimi olarak iki alt kola ayrılabilir. Genel iş Türkçesi öğretimi, dil etkinlikleri açısından genel amaçlı Türkçe kurslarına benzemekle birlikte iş bağlamında hazırlanmış materyalleriyle ve söz varlığı ile onlardan ayrılır. Bu kurslar, iş deneyimi olmayan ya da iş hayatına henüz yeni atılmış öğrenicilere yöneliktir. Özel iş Türkçesi öğretimi, iş bilgisi ve becerisi bakımından deneyimli öğrenicilere yönelik olup belirli iş iletişimi durumlarına, iş bağlamlarına ve dil becerilerine yoğunlaşan faydacı, pratik ve esnek bir yapıdadır. Öğretimin içeriği; iş verenlerin, öğrenicilerin ve öğreticilerin müzakeresi ile belirlenir.

Türkçe son yıllarda yabancılar tarafından iş dili olarak öğrenimi talep edilen bir dildir. Bazı durumlarda iş verenler, yabancı çalışanlarının iş Türkçesi kurslarına katılmalarını teşvik edebilir ya da yabancı çalışanlar, iş bulmak ya da mesleki kariyerlerinde yükselmek, belirli dilsel ya da mesleki becerilerde kendilerini geliştirmek için bu kursları talep edebilir. İş Türkçesi öğreticilerinin iş Türkçesi kurslarının materyal, program, ölçme-değerlendirme gibi ögelerinin hazırlanmasında kendi beklentilerinden çok işverenlerin ve öğrenicilerin "beklenti” ve “ihtiyaçlarını" göz önünde bulundurması gerekir. Öte yandan kurs öğreticilerinin ve materyal tasarımcılarının, iş Türkçesi öğretiminin aşă̆ıda sıraladığımız özelliklerini dikkate almaları önemlidir:

1. Bir mesleğe ya da iş yerine yöneliktir: Hedef kitlesi "beyaz yakalı" kesimin dâhil olduğu bankacılık, finans, insan kaynakları, ithalat-ihracat, yönetim gibi doğrudan ticari sahada baş gösteren iş adamları ve meslek sahipleridir. Öğrenicileri mesleki olarak deneyimli ya da deneyimsiz olabilir; mevcut işlerini veya gelecekteki işlerini daha etkili bir şekilde yapmalarına yardımcı olacak iş Türkçesini öğrenmek isteyebilirler.

2. "İ̧" ile ilgili konuları kapsar: Öğretimin içeriği ağırlıkı olarak ilgili meslek grubunun ilgilendiği konulara göre belirlenir. Örnek olarak halkla ilişkiler bölümünde çalışan bir öğrenici öncelikle ihtiyacı olan söz varlığını kazanmak ve alanına özel becerileri kazanmak isteyebilir. Dolayısıyla öğretim materyalleri halkla ilişkiler alanından seçilmelidir.

3. Zamanı etkili kullanmaya yöneliktir: İş adamları genellikle çalışma hayatlarının dışındaki zamanlarda dil öğrenmek isterler ve her zaman meşgullerdir. Dolayısıyla bütün bir dil bilgisini ve söz varlığını öğrenmek yerine onları kısa sürede ihtiyaç duydukları dili ve becerileri öğretecek kursları talep ederler. İş Türkçesi öğretiminde faydacı bir yaklaşımla haftalık ders saatleri kısıtlı tutulur; zaman etkili ve verimli kullanılır. Aksi takdirde iş adamlarının kursa olan ilgileri düşer ve kurs başarısız olur.

4. İletişimsel becerileri geliştirmeye yöneliktir: İş dünyasının iletişim biçimleri ortaktır ve iş adamları iletişimlerini bu şekilde sağlar. İş Türkçesinin temel etkinlik alanları konuşma/dinleme becerileri için sosyalleşme, ayaküstü konuşmalar, telefon görüşmeleri, sunum, toplantı, pazarlık; yazma/okuma becerileri için yazışmalar, sözleşme, rapor, tutanak, öz geçmiş ve internet yazılarıdır. Bu alanlar ihtiyaçlara bağlı olarak çeşitlendirilebilir.

5. İletişimsel yeterliğin rolü: İş Türkçesi öğretiminde iletişimsel yeterliğin rolü göz ardı edilemez. Bu noktada öğrenicinin söz varlığının genişliği ya da dil bilgisi konularına hâkimiyetindense "iş" ile ilgili yerine getirmesi gereken muhtemel ya da mevcut görevleri ne düzeyde yerine getirdiğinin önemi ortaya çlkar. Orta düzeyde genel Türkçe bilgisine sahip bir öğrenici; ileri düzey Türkçe bilgisine sahip bir öğreniciden daha etkili sunum yapabiliyor, etkili bir şekilde toplantılara katılabiliyor ya da pazarlık yapabiliyorsa bu durum o öğrenicinin iş Türkçesi kapsamındaki iş beceriyle, mesleki bilgisiyle ya da beden dilini etkili kullanmasıyla ilgili olabilir.

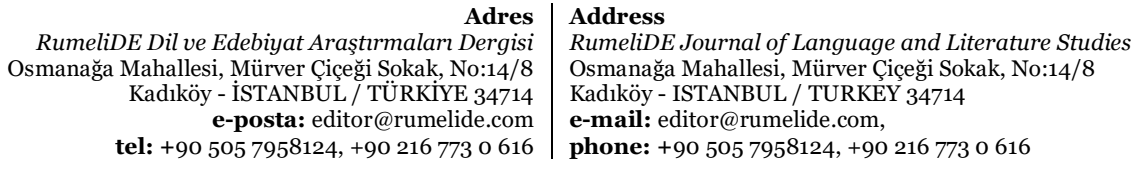


6. İş Türkçesi “öğretimi”, ilgili mesleğe yönelik bir "eğitim” süreci olarak düşünülmelidir: Özel amaçlı dil öğreticisinin kapsamlı rolleri düşünüldüğünde öğretici zaman zaman iş dili ve becerilerini kazandıran, öğrenicilerine kendi başlarına öğrenme stratejileri sağlayan mesleki bir "yaşam koçuna" dönüştüğü görülür. Bu bağlamda kurslar hizmet içi eğitim kurslarına dönüşebilir.

7. İş Türkçesinde taraflar: İş Türkçesi öğrenicileri işleri çerçevesinde hem müşterileriyle hem de kendi iş yerlerinden iş arkadaşlarıyla ya da diğer şirketlerden meslektaşlarıyla iş dilini kullanırlar. Bu da öğretilecek dilin içeriğini ve kapsamını belirler.

8. İş Türkçesi öğretimi “işi” konu edinen bir meslektir: Bu bağlamda öğreticilerinin giyim kuşamları, her türlü hal ve hareketleri, kullandıkları materyallerin kaliteleri ile her yönüyle profesyonel görünmesi son derece önemlidir. Nitekim meslek sahibi öğreniciler karşılarında profesyonel bir öğrenici görmek isteyeceklerdir.

9. İş Türkçesi bir yönüyle genel amaçlı Türkçedir: İş dili, sadece işle ilgili dili, konuları ve becerileri kapsayan bir yapıda değildir. İş adamları gerek iş arkadaşlarıyla gerekse müşterileriyle çeşitli sebeplerle gündelik konularda iletişim kurmak durumundadır. Sosyalleşme amaçlı hava durumu, hafta sonu etkinlikleri, spor haberleri gibi konularda gerçekleştirilecek ayaküstü sohbetler iş dilinin olmazsa olmazlarındandır. Bu durum öğretimde dikkate alınmalıdır.

10. İş seyahatleri: İş adamları için çeşitli sebeplerle iş seyahatlerine çımak olağan bir durumdur. Dolayısıyla iş Türkçesi öğretiminde iş adamlarına seyahatlerine yönelik dil becerisi kazandırmak da önemlidir.

11. İş Türkçesi verileri: İnsanların günlük yaşamda nasıl iletişim kurduğu ile ilgili neredeyse sınırsız veri mevcutken iş dünyasında gizlilik ve güvenlik ihtiyacının yüksek olması sonucunda sınırlı iş Türkçesi verisi mevcuttur. Buna iş Türkçesine dair çalışmaların yetersizliği de bir başka neden olarak eklenebilir. $\mathrm{Bu}$ durum materyal hazırlayıcıları açısından bir engel teşkil edebilir.

12. Kültürel boyut: İş Türkçesi öğretiminde iş kültürüne dair ögelerin öğretimi öğrenicilerin iş hayatında başarıya ulaşmasında önemli bir etkendir.

13. Öğretim ortamı: Genel Türkçe öğretiminin aksine öğretim, sınıfın dışında zaman zaman bir fabrika ya da şirkette gerçekleştirilebilir.

\section{Sonuç}

Özel amaçlı dil öğretimi yabancı dil olarak Türkçenin bir alt kolu olarak çeşitli dallarıyla giderek artan bir taleple karşılaşmaktadır. Sahadaki kuramsal bilgilerin sınırlılığı çeşitli kafa karışıklıklarını ve tanımlarda eksiklikleri doğurmaktadır. Bu durum hazırlanan materyallerin de amaçlarına ulaşmasına engel teşkil etmektedir. Çalışmamızda dünyadaki alanyazın göz önünde bulundurularak özel amaçlı dil öğretiminin ve alt dallarının tanımı, sınıflandırılması yapılmıştır. Bu alt dallar arasında gördüğü taleple öne çıkan iş dili öğretimi de tanımlanıp sınıflandırılmıştır.

Özel amaçlı dil öğretimi öğrenici ihtiyaçlarını esas alır. Genel amaçlı dil öğretimi kurslarında da öğrenicilerin çeşitli öğrenme ihtiyaçları olabilir. Bu ihtiyaçları dikkate alan öğreticiler kursun yapısında değişikliklere gidebilirler. Ancak öğretimin özel amaçlı dil öğretimi olarak sınıflandırılabilmesi ihtiyaçların "akademik" ya da "mesleki” olup olmadığıyla ilgilidir.

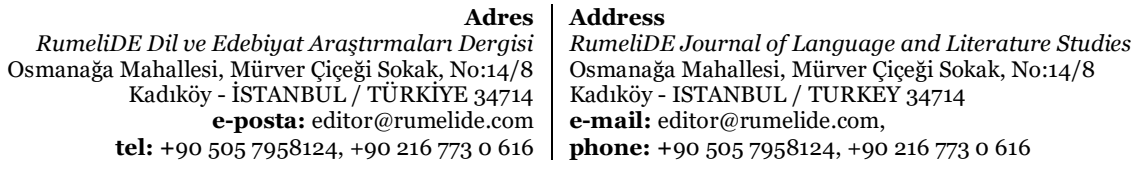


Business Turkish in the context of teaching Turkish for specific purposes to foreigners: definitions and limitations / V. Kurt (pp. 1-9)

$\mathrm{Bu}$ ayrımlar yapılırken dilin nasıl özelleştĭgini anlamaya çalışmak kurs tasarımında ve materyal üretiminde başarıya ulaşmayı sağlar. Akademik amaçlı dil öğretiminde öğrenicilere not tutmak, rapor yazmak, ders kitabını kullanmak, seminer vermek veya bir semineri dinlemek, öğrenci işleri ile ilgili yazışmaları okumak ve yazmak, tez savunmalarına katılmak vb. beceriler üzerinden dilin verilmesi amaçlanır. Burada öğretimin ve dilin akademik amaçlarla özelleştiği görülür. Mesleki amaçlı dil öğretiminde ise söz konusu mesleğe uygun söz varlığı, o mesleğin bağlamları da göz önünde bulundurularak çeşitli iletişim durumları ile verilir. Burada da öğretimin ve dilin mesleki beceriler bağlamında özelleştiği görülür. Akademik amaçlı dil öğretimi öğrenicilerine öğrenim becerileri kazandırmayı amaçlarken mesleki amaçlı dil öğretimi ise öğrencilerine mevcut ya da ileride meslek hayatlarında ihtiyaçları olan/olacak dil ve becerileri kazandırmayı amaçlar.

Gerek akademik amaçlı dil öğretiminde gerekse mesleki amaçlı dil öğretiminde öğrenicilerin öğrenimlerine akademik ya da mesleki kariyerlerindeki konumlarına bağlı olarak kurslara başlama dönemleri önemlidir. Deneyimli öğreniciler, sınıf ortamına alanlarıyla ilgili belirli bir ölçüde söz varlığı bilgisiyle ve becerilerle gelirken deneyimsiz öğreniciler böyle bir donanımdan yoksun olarak sınıfa gelir. Dolayısıyla özel amaçlı dil öğretiminde kursun içeriği belirlenirken öğrenicilerin kariyer konumları da dikkate alınmalıdır.

Mesleki amaçlı Türkçe öğretiminin bir alt kolu olan iş Türkçesi öğretiminde dilin işe dair bağlamlarda sosyalleşme, telefon görüşmesi, sohbet, sunum, müzakere/pazarlık vd. temel iletişimsel etkinlik alanlarında özelleştiği görülür. Esas olan işe dair dil unsurlarının ve becerilerin öğretilmesidir. İş dilinin günlük iletişim dilini de kapsayan bir yönü vardır. İş adamları, iş arkadaşlarıyla ya da müşterileriyle konuşurken çeşitli bağlamlarda günlük iletişim dilinden yararlanırlar. Bu durum iş Türkçesi öğretiminin diğer mesleki amaçlı Türkçe öğretimi kollarından ayrılmasını sağlayan bir özelliktir. Tıp, hukuk, askerlik Türkçesi öğretimi gibi alanlarda günlük iletişim dilinden bu derece yararlanılmaz. Bünyesinde genel iletişim dilini, iş dilini ve iş becerilerini barındırması nedeniyle iş Türkçesi öğretimine B1 eşik düzeyden itibaren başlamak uygundur. Dünyadaki uygulamalar incelendiğinde iş dili öğretiminde B1 eşik düzeyin yaygın olarak tercih edildiği görülür.

İş Türkçesi öğretiminin genel çatısına bakıldığında işle ilgili konuların ve iş becerilerinin merkeze alındığı, zamanı doğru kullanmanın ve temel iletişimsel etkinlik alanlarına uygun olarak iletişimsel becerilerin öncelendiği, öğreticinin öğrenicileri destekleyici rolünün önemli olduğu, genel iletişim dilini ve iş seyahatleri için gerekli dil becerilerini de kapsadığı görülmektedir. İş Türkçesi öğretiminde yerel ve ulusal kültür unsurlarının dikkate alınması gerektiği aşikardır. İş Türkçesi araştırmacılarını bekleyen temel sorunlardan biri güvenlik ve gizlilik gibi nedenlerden ötürü iş Türkçesi verilerine ulaşmanın güçlüğü ve alanda yapılmış çalışmaların azlığıdır. Alanda yapılacak çalışmalarda yukarıda verilen özelliklerin göz önünde bulundurulması Türkçenin iş dili olarak dünya dilleri arasında prestijinin artmasını sağlayacaktır.

\section{Kaynakça}

Baştürkmen, H. (2006). Ideas and Options in English for Specific Purposes. London: Lawrence Erlbaum Associates.

Belcher, D. (2006). English for Specific Purposes: Teaching to Perceived Needs and Imagined Futures in Worlds of Work, Study, and Everyday Life. TESOL Quarterly, 4O(1), 133-156. doi:10.2307/40264514

Barın, E.; Temizyürek, F. (2018). Balkanlarda Yabancı Dil Olarak Türkçe Öğretiminde Materyal İhtiyacı. Uluslararası Türk Kültürü ve Dili Sempozyumu (s.3-5). Üsküp, Makedonya.

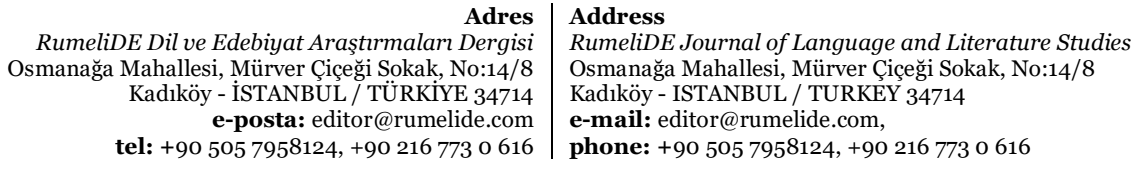


Dudley-Evans, T. D., St. John M. J. (1998). Developments in English for Specific Purposes: A MultiDisciplinary Approach. Cambridge: Cambridge University Press.

Hutchinson, T.; Waters, A. (1991). English for Specific Purposes. Great Britain: Cambridge University Press.

Hyland, K. (2006). English For Academic Purposes: Anadvanced Resource Book. London, England: Routledge.

Kurt, V. (2020). Yabancllar İçin Özel Amaçl Türkçe Öğretimi: İş Türkçesi. Adana: Karahan Kitabevi.

Mackay, R., Mountford, A. (1978). English for Specific Purposes (Applied Linguistics and Language Study). London: Longman.

T.C. Aile, Çalışma ve Sosyal Hizmetler Bakanlığı. (2019). Çalışma Hayatı İstatistikleri (Yayın no: Belirtilmemiş). Erişim: 10 Şubat 2021, https://www.ailevecalisma.gov.tr/media/63359/calisma_hayati_2019.pdf

Türkiye Odalar ve Borsalar Birliği. (2021) Kurulan/Kapanan Şirket İstatistikleri. TOBB. Erişim: 1 Mart 2021, https://tobb.org.tr/BilgiErisimMudurlugu/Sayfalar/KurulanKapananSirketistatistikleri.php

Woodrow, L. (2018). Introducing Course Design in English for Specific Purposes. New York: Routledge.

RumeliDE Dil ve Edebiyat Araştırmaları Dergisi Osmanağa Mahallesi, Mürver Çiçeği Sokak, No:14/8 Kadıköy - İSTANBUL / TÜRKIYE 34714 e-posta: editor@rumelide.com tel: +90 $5057958124,+902167730616$
Address

RumeliDE Journal of Language and Literature Studies Osmanağa Mahallesi, Mürver Çiçeği Sokak, No:14/8

Kadıköy - ISTANBUL / TURKEY 34714

e-mail: editor@rumelide.com,

phone: +90 $5057958124,+902167730616$ 